Article

\title{
A novel dicobalt-substituted tungstoantimonate polyoxometalate: Synthesis, characterization, and photocatalytic water oxidation properties
}

\author{
Qing Han a, Di Sun c, Junwei Zhao d, Xiangming Liang a , Yong Ding a,b,* \\ a State Key Laboratory of Applied Organic Chemistry, Key Laboratory of Nonferrous Metals Chemistry and Resources Utilization of Gansu Province, and \\ College of Chemistry and Chemical Engineering, Lanzhou University, Lanzhou 730000, Gansu, China \\ b State Key Laboratory for Oxo Synthesis and Selective Oxidation, Lanzhou Institute of Chemical Physics, Chinese Academy of Sciences, Lanzhou 730000, \\ Gansu, China \\ Key Laboratory of Colloid and Interface Chemistry, Ministry of Education, School of Chemistry and Chemical Engineering, Shandong University, Jinan \\ 250100, Shandong, China \\ d Henan Key Laboratory of Polyoxometalate Chemistry, Institute of Molecule and Crystal Engineering, College of Chemistry and Chemical Engineering, \\ Henan University, Kaifeng 475004, Henan, China
}

\section{A R T I C L E I N F O}

\section{Article history:}

Received 23 January 2019

Accepted 25 March 2019

Published 5 June2019

\section{Keywords:}

Light-driven water oxidation

Tungstoantimonate

Self-assembly

\begin{abstract}
A B S T R A C T
The one-pot assembly reaction of a trilacunary, lone-pair-containing $\left[B-\alpha-\mathrm{SbW}_{9} \mathrm{O}_{33}\right]^{9-}$ precursor with $\mathrm{Co}^{2+}$ ions in an aqueous medium led to the isolation of a novel $\left\{\mathrm{SbO}_{3}\left(\mathrm{H}_{2} \mathrm{O}\right)_{3}\right\}$ bridging, dicobalt-substituted, sandwich-type tungstoantimonate $\left\{\mathrm{Co}_{2} \mathrm{Sb}_{2}\left(\mathrm{H}_{2} \mathrm{O}\right)_{10}\left[B-\beta \text { - } \mathrm{SbW}_{9} \mathrm{O}_{33}\right]_{2}\right\}^{4-}$ (1a). This compound was structurally characterized in the solid state by single-crystal X-ray diffraction, elemental analyses, thermogravimetric analysis, and IR spectroscopy. The most remarkable feature was that 1a comprises two trilacunary $\left[B-\beta-\mathrm{SbW}_{9} \mathrm{O}_{33}\right]^{9-}$ fragments trapping a novel, centrally symmetric, rhomb-like $\left\{\mathrm{Co}_{2} \mathrm{Sb}_{2}\right\}$ belt with 10 terminal water molecules. When combined with the photosensitizer $\left[\mathrm{Ru}(\mathrm{bpy})_{3}\right]^{2+}$ and the sacrificial electron acceptor $\mathrm{S}_{2} \mathrm{O}_{8}{ }^{2-}$, 1a exhibited efficient catalytic activity for water oxidation with a remarkable turnover number (TON) of 193, initial turnover frequency ( $\left.\mathrm{TOF}_{\text {initial }}\right)$ of $5.3 \mathrm{~s}^{-1}, \mathrm{O}_{2}$ yield of $30.8 \%$, and quantum yield $\left(\Phi_{\mathrm{QY}}\right)$ of $36.2 \%$ under light-driven conditions.
\end{abstract}

(C) 2019, Dalian Institute of Chemical Physics, Chinese Academy of Sciences. Published by Elsevier B.V. All rights reserved.

\section{Introduction}

Light-driven water splitting to hydrogen and oxygen, which is one of the most desirable and promising strategies to resolve the current energy and environmental crisis, has been receiving much attention [1-4]. Water oxidation (WO) $\left(2 \mathrm{H}_{2} \mathrm{O} \rightarrow 4 \mathrm{H}^{+}+\right.$ $4 \mathrm{e}^{-}+\mathrm{O}_{2}$ ) is considered the bottleneck in water splitting during the energy conversion scheme, in both natural and artificial photosynthesis [5], which requires efficient and stable water oxidation catalysts (WOCs) [6,7]. In the last few decades, worldwide research efforts have contributed to the design of robust and highly active homogeneous and heterogeneous WOCs [8-12].

In the field of homogeneous WOCs, polyoxometalates (POMs) [13-15], an excellent class of molecular metal-oxygen clusters with highly oxidized early transition metals (TM), have

\footnotetext{
* Corresponding author. E-mail: dingyong1@lzu.edu.cn

This research was financially supported by the National Natural Science Foundation of China (21773096), the Fundamental Research Funds for the Central Universities (lzujbky-2018-k08), and the Natural Science Foundation of Gansu Province (17JR5RA186).

DOI: S1872-2067(19)63358-9 | http://www.sciencedirect.com/science/journal/18722067 | Chin. J. Catal., Vol. 40, No. 6, June2019
} 
attracted widespread attention. This is because of their ability to undergo fast, reversible, and stepwise multielectron-transfer reactions without changing their structures due to their high oxidative, thermal, and hydrolytic stability [16-20]. In 2009, Hill and co-workers [21] reported the first use of a tetraruthenium polyoxometalate complex, $\left[\left\{\mathrm{Ru}_{4} \mathrm{O}_{4}(\mathrm{OH})_{2}\left(\mathrm{H}_{2} \mathrm{O}\right)_{4}\right\}\right.$ $\left.\left(\mathrm{SiW}_{10} \mathrm{O}_{36}\right)_{2}\right]^{10-}$, to catalyze WO in a totally homogeneous, visible light-driven, and artificial photosynthesis system at neutral $\mathrm{pH}$. In 2011, they found that a cobalt-based POM, $\left[\mathrm{Co}_{4}\left(\mathrm{H}_{2} \mathrm{O}\right)_{2}\left(\mathrm{PW}_{9} \mathrm{O}_{34}\right)_{2}\right]^{10-}$ (abbreviated as $\left.\mathrm{Co}_{4} \mathrm{P}_{2} \mathrm{~W}_{18}\right)$, was competent as an efficient molecular catalyst for the visible light-driven catalytic oxidation of water [22]. In 2014, Wang's group [23] reported on a series of high-nuclearity cobalt-based POM-WOCs such as $\left[\left\{\mathrm{Co}_{4}(\mathrm{OH})_{3}\left(\mathrm{PO}_{4}\right)\right\}_{4}\left(\mathrm{SiW}_{9} \mathrm{O}_{34}\right)_{4}\right]^{32-}$, $\left[\left\{\mathrm{Co}_{4}(\mathrm{OH})_{3}\left(\mathrm{PO}_{4}\right)\right\}_{4} \quad\left(\mathrm{GeW}_{9} \mathrm{O}_{34}\right)_{4}\right]^{32-}, \quad\left[\left\{\mathrm{Co}_{4}(\mathrm{OH})_{3}\left(\mathrm{PO}_{4}\right)\right\}_{4-}\right.$ $\left.\left(\mathrm{PW}_{9} \mathrm{O}_{34}\right)_{4}\right]^{28-}$, and $\left[\left\{\mathrm{Co}_{4}(\mathrm{OH})_{3}\left(\mathrm{PO}_{4}\right)\right\}_{4}\left(\mathrm{AsW}_{9} \mathrm{O}_{34}\right)_{4}\right]^{28-}$. This study not only provides a valuable molecular model structurally analogous to the $\left[\mathrm{Mn}_{3} \mathrm{O}_{5} \mathrm{Ca}\right.$ ] core but also an unprecedented opportunity to construct polynuclear TM-based POM-WOCs for visible light-driven WO. Our group has worked extensively in this area and reported a highly stable and effective mixed-valence WOC $\left[\mathrm{Co}^{\mathrm{III}} \mathrm{Co}^{\mathrm{II}}\left(\mathrm{H}_{2} \mathrm{O}\right) \mathrm{W}_{11} \mathrm{O}_{39}\right]^{7-}$ in 2013 and a mononuclear cobalt(II)-substituted silicotungstate WOC $\left[\mathrm{Co}\left(\mathrm{H}_{2} \mathrm{O}\right)_{2}\left(\gamma-\mathrm{SiW}_{10} \mathrm{O}_{35}\right)_{2}\right]^{10-}$ in $2014[24,25]$. Recently, we had reported an oxidatively and hydrolytically stable bioinspired molecular WOC based on a polyoxometalate $\left[\left(\mathrm{SiW}_{9} \mathrm{O}_{34}\right)_{2} \mathrm{Co} 8(\mathrm{OH})_{6}\left(\mathrm{H}_{2} \mathrm{O}\right)_{2}\left(\mathrm{CO}_{3}\right)_{3}\right]^{16-}$, which exhibited excellent WO activity with a very high turnover number (TON) of 1436 [26].

There are very few reports on TM-substituted tungstoantimonates that act as WOCs, because $\mathrm{Sb}^{3+}$ hydrolyzes in aqueous solutions, which to a great extent impedes combination with TM ions into POM clusters. A majority of the addressed TM-substituted tungstoantimonates were prepared through the assembly of the trivacant Keggin polyoxoanion $\left[\mathrm{SbW}_{9} \mathrm{O}_{33}\right]^{9-}$ with different types of TM ions [27-34]. This is of great interest to us, as it provides an excellent opportunity to further research on tungstoantimonate incorporating TM clusters. Thus, we adopted a one-pot self-assembly strategy that allowed us to effectively prepare a novel TMSP by integrating the well-defined secondary building blocks $\left[\mathrm{SbW}_{9} \mathrm{O}_{33}\right]^{9-}$ with $\mathrm{Co}^{2+}$ ions.

Herein, we first synthesized an octahedral, $\left\{\mathrm{SbO}_{3}\left(\mathrm{H}_{2} \mathrm{O}\right)_{3}\right\}$ bridging, dicobalt-substituted, sandwich-type tungstoantimonate $\left[\mathrm{Na}_{4}\left\{\mathrm{Co}_{2} \mathrm{Sb}_{2}\left(\mathrm{H}_{2} \mathrm{O}\right)_{10}\left(B-\beta-\mathrm{SbW}_{9} \mathrm{O}_{33}\right)\right\}_{2}\right] \cdot 39 \mathrm{H}_{2} \mathrm{O}(\mathbf{1})$ and found that it could be used as a homogeneous catalyst for the efficient production of $\mathrm{O}_{2}$ under visible-light irradiation. Under the optimal photocatalytic conditions, i.e., photoirradiation at $\lambda=460$ nm with $\left[\mathrm{Ru}(\text { bpy) })_{3}\right] \mathrm{Cl}_{2}$ as a photosensitizer and $\mathrm{Na}_{2} \mathrm{~S}_{2} \mathrm{O}_{8}$ as an oxidant in borate buffer $(\mathrm{pH}=8.5)$, the TON could reach a value as high as 193 with an $\mathrm{O}_{2}$ yield of $30.8 \%$. The initial quantum yield $\left(\Phi_{\mathrm{QY}}\right)$ and initial turnover frequency (TOFinitial) in the first $20 \mathrm{~s}$ were $36.2 \%$ and $5.3 \mathrm{~s}^{-1}$, respectively. Variables of the photocatalytic reaction, including catalyst concentration, buffer type and concentration, $\mathrm{pH}$, dye concentrations, and oxidant concentration, were systemically studied.

\section{Experimental}

\subsection{Synthesis of $\mathbf{1}$}

$\left[\mathrm{Na} 9\left(B-\alpha-\mathrm{SbW}_{9} \mathrm{O}_{33}\right)\right] \cdot 19.5 \mathrm{H}_{2} \mathrm{O}$ was prepared as described in the literature and confirmed based on the IR spectra [35]. Other common laboratory chemicals were analytically pure, purchased from commercial sources, and used without further purification.

$\mathrm{Na} 9\left[B-\alpha-\mathrm{SbW}_{9} \mathrm{O}_{33}\right] \cdot 19.5 \mathrm{H}_{2} \mathrm{O}(2.004 \mathrm{~g}, 0.70 \mathrm{mmol}), \mathrm{AgNO}_{3}$ (0.102 g, $0.60 \mathrm{mmol})$, and $\mathrm{Co}\left(\mathrm{NO}_{3}\right)_{2} \cdot 6 \mathrm{H}_{2} \mathrm{O}(0.152 \mathrm{~g}, 0.52 \mathrm{mmol})$ were dissolved in $30 \mathrm{~mL}$ of deionized water with stirring, and the $\mathrm{pH}$ of the solution was carefully adjusted to 4.0 at room temperature by the addition of dilute $\mathrm{HNO}_{3}$ solution ( $\left.6 \mathrm{~mol} / \mathrm{L}\right)$. The solution was stirred continuously for $1 \mathrm{~h}$, heated at $80{ }^{\circ} \mathrm{C}$ for $3 \mathrm{~h}$, and then filtered upon cooling to room temperature. Slow evaporation of the filtrate for two weeks at room temperature led to the formation of purple cubic block crystals of $\mathbf{1}$. Yield: ca. $28 \%$ (based on $\mathrm{Co}\left(\mathrm{NO}_{3}\right)_{2} \cdot 6 \mathrm{H}_{2} \mathrm{O}$ ). Anal. Calcd (\%) for $\mathrm{H}_{98} \mathrm{Co}_{2} \mathrm{Na}_{4} \mathrm{O}_{115} \mathrm{Sb}_{4} \mathrm{~W}_{18}$ : H 1.66, Na 1.54, Co 1.98, Sb 8.19; found: H 1.90, Na 2.42, Co 1.81, Sb 8.25. IR (KBr pellets, $\mathrm{cm}^{-1}$ ): 3432 (vs), 1623 (s), $925(\mathrm{~m}), 894(\mathrm{~m}), 770(\mathrm{w}), 706(\mathrm{w}), 611(\mathrm{w})$, $518(\mathrm{w}), 445(\mathrm{~m})$.

\subsection{Photocatalytic WO experiments}

The photocatalytic WO was performed as follows. In a typical experiment, $10 \mathrm{~mL}$ of $80 \mathrm{mmol} / \mathrm{L}$ sodium borate buffer $(\mathrm{pH}$ 8.0-9.4) containing $\left[\mathrm{Ru}(\mathrm{bpy})_{3}\right] \mathrm{Cl}_{2}(0-1.5 \mathrm{mmol} / \mathrm{L}), \mathrm{Na}_{2} \mathrm{~S}_{2} \mathrm{O}_{8}$ $(0-7.0 \mathrm{mmol} / \mathrm{L})$, and $\mathbf{1}(4.0 \mu \mathrm{mol} / \mathrm{L})$ were introduced in a glass reactor sealed with a rubber septum. The above solution was deaerated by purging it with Ar gas for 5 min in a flask (21 mL) sealed with a rubber septum. The reaction was initiated by irradiating the solution with an LED (light intensity $33.8 \mathrm{~mW}$, beam diameter $2 \mathrm{~cm})$ through a transmitting glass filter $(\lambda=$ $460 \mathrm{~nm}$ ) at room temperature. After each sampling time, 100 $\mathrm{mL}$ of Ar was injected into the flask, and the same volume of the gas sample in the headspace of the flask was withdrawn by an SGE gas-tight syringe and analyzed by gas chromatography (GC). $\mathrm{O}_{2}$ in the sampled gas was separated by passing the gas through a $2 \mathrm{~m} \times 3 \mathrm{~mm}$ packed molecular sieve (5 A) column with $\mathrm{Ar}$ as the carrier gas and quantified by a thermal conductivity detector (TCD). The total amount of $\mathrm{O}_{2}$ evolved was calculated from the concentration of $\mathrm{O}_{2}$ in the headspace gas. Air contamination in the headspace was corrected by measuring the $\mathrm{N}_{2}$ concentration present in the headspace. The turnover number is defined as TON $=\left(\mathrm{O}_{2}\right.$ yield at end of run $) /$ (catalyst concentration $)=\left(\mathrm{mol}\right.$ of $\left.\mathrm{O}_{2}\right) \mathrm{f} /(\mathrm{mol}$ of catalyst $)$. The $\mathrm{O}_{2}$ yield is defined as $\mathrm{O}_{2}$ yield $=2 \times\left(\mathrm{mol} \text { of } \mathrm{O}_{2}\right)_{\mathrm{f}} /\left(\mathrm{mol}\right.$ of $\left.\mathrm{Na}_{2} \mathrm{~S}_{2} \mathrm{O}_{8}\right)$. The initial TOF for oxygen evolution is defined as $\mathrm{TOF}_{\text {initial }}=(\mathrm{mol}$ of $\mathrm{O}_{2}$ ) / (mol of catalyst $\times 20 \mathrm{~s}$ ), based on the amount of evolved $\mathrm{O}_{2}$ after $20 \mathrm{~s}$ of visible-light irradiation.

\subsection{Characterization technique}

A single crystal of $\mathbf{1}$ with the appropriate dimensions was chosen, quickly coated with high-vacuum grease, and mounted 
on a glass fiber. The intensity data were recorded on a Bruker Apex II diffractometer using graphite-monochromated $\mathrm{Cu} K_{\alpha}$ radiation $(\lambda=0.71073 \AA$ A). IR spectra were obtained using a Bruker VERTEX 70v FT-IR spectrometer with 2-4 wt\% sample in $\mathrm{KBr}$ pellets in the range of $4000-400 \mathrm{~cm}^{-1}$. Inductively coupled plasma-atomic emission spectrometry (ICP-AES) was performed with a TJA ICP-atomic emission spectrometer (IRIS Advantage ER/S). Thermogravimetric analysis (TGA) was carried out using a Linseis STA PT1600 in the temperature range $25-850{ }^{\circ} \mathrm{C}$, at a heating rate of $10 \mathrm{~K} \mathrm{~min}^{-1}$, in $\mathrm{N}_{2}$ atmosphere. UV-Vis absorption data were obtained using a TU-1810 spectrophotometer equipped with a photomultiplier tube detector. $\mathrm{C}, \mathrm{H}$, and $\mathrm{N}$ elemental analyses were performed using a Vario EL CHNS/O analyzer. Powder X-ray diffraction (PXRD) measurements were carried out on, a Rigaku D/MAX 2400 diffractometer operated at $40 \mathrm{kV}$ and $40 \mathrm{~mA}$ with $\mathrm{Cu} K_{\alpha}$ radiation $(\lambda=$ $1.54056 \AA$ ). Photon flux of the incident light was determined using a Ray virtual radiation actinometer (FU 100, silicon ray detector, light spectrum 400-700 $\mathrm{nm}$, sensitivity 10-50 $\mu \mathrm{V}$ $\mu \mathrm{mol}^{-1} \mathrm{~m}^{-2} \mathrm{~s}^{-1}$ ), which afforded a value of $1600 \mu \mathrm{mol} \mathrm{m}^{-2} \mathrm{~s}^{-1}$.

\section{Results and discussion}

\subsection{Crystal structure}

The crystallographic data and structural refinements are summarized in Table S1 (see the Supporting Information). The crystallographic data for $\mathbf{1}$ were deposited at the Cambridge Crystallographic Data Center with CCDC 1835378. Bond valence sum (BVS) (Tables S2 and S3) calculations revealed that the oxidation states of all the Co and $\mathrm{W}$ atoms were +2 and +6 , respectively. The oxidation states of the $\mathrm{Sb} 1$ and $\mathrm{Sb} 2$ atoms were +3 and +5 , respectively. The presence of $\mathrm{Sb}^{5+}$ ions in the final product suggested that some of the $\mathrm{Sb}^{3+}$ ions were oxidized by $\mathrm{Ag}^{+}$ions in the presence of $\mathrm{O}_{2}$ for the formation of $\mathbf{1}$.

The new dicobalt-substituted and sandwiched tungstoantimonate dimer $\left[\mathrm{Na}_{4}\left\{\mathrm{Co}_{2} \mathrm{Sb}_{2}\left(\mathrm{H}_{2} \mathrm{O}\right)_{10}\left[B-\beta-\mathrm{SbW}_{9} \mathrm{O}_{33}\right]_{2}\right\}\right] \cdot 39 \mathrm{H}_{2} \mathrm{O}$ (1) was synthesized by the reaction of $\mathrm{Co}^{2+}$ ions with trilacunary POM precursor $\left[B-\alpha-\mathrm{SbW}_{9} \mathrm{O}_{33}\right]^{9-}$ in a weakly acidic aqueous medium, and it crystallized in the monoclinic space group $P 2_{1} / c$. The molecular structure of $\mathbf{1}$ consists of one dimeric $\left\{\mathrm{Co}_{2} \mathrm{Sb}_{2}\left(\mathrm{H}_{2} \mathrm{O}\right)_{10}\left[B-\beta-\mathrm{SbW}_{9} \mathrm{O}_{33}\right]_{2}\right\}^{4-}$ (1a) cluster (Fig. 1a and $1 \mathrm{~b}$ ), four sodium ions, and thirty-nine lattice water molecules. Compound $\mathbf{1 a}$ is composed of two trivacant $\left[\mathrm{B}-\beta-\mathrm{SbW}_{9} \mathrm{O}_{33}\right]^{9-}$ units (Fig. 1c) linked together by a $\left\{\mathrm{Co}_{2} \mathrm{Sb}_{2}\right\}$ belt (Fig. 1e), in which two inner $\mathrm{Sb}^{3+}$ ions ( $\left.\mathrm{Sb} 1, \mathrm{Sb} 1 \mathrm{~A}\right)$ and two outer $\mathrm{Co}^{2+}$ ions (Co1, Co1A) lie at the corners of a rhombus with two adjacent edges of 5.789 and $5.897 \AA$, and all ions adopt the six-coordinate octahedral geometry (Fig. 1f and 1g).

The trivacant $\left.\left[B-\beta-\mathrm{SbW}_{9} \mathrm{O}_{33}\right)\right]^{9-}$ subunit is derived from the trilacunary $\left[B-\alpha-\mathrm{SbW}_{9} \mathrm{O}_{33}\right]^{9-}$ (Fig. $1 \mathrm{~d}$ ) anion by rotating one of the edge-shared $\left\{\mathrm{W}_{3} \mathrm{O}_{13}\right\}$ groups. Moreover, it is particularly interesting to note that the sandwich-type $\left\{\mathrm{Co}_{2} \mathrm{Sb}_{2}\left(\mathrm{H}_{2} \mathrm{O}\right)_{10^{-}}\right.$ $\left.\left[B-\beta \text {-SbW }{ }_{9} \mathrm{O}_{33}\right]_{2}\right\}^{4-}$ polyanion in $\mathbf{1}$ is the first reported example of a compound bearing the $\left\{\mathrm{Co}_{2} \mathrm{Sb}_{2}\right\}$ moiety. We believe that isomerization of the $\left[B-\alpha-\mathrm{SbW}_{9} \mathrm{O}_{33}\right]^{9-}$ precursor and degradation of the $\left[\mathrm{SbW}_{9} \mathrm{O}_{33}\right]^{9-}$ building block must have occurred dur-

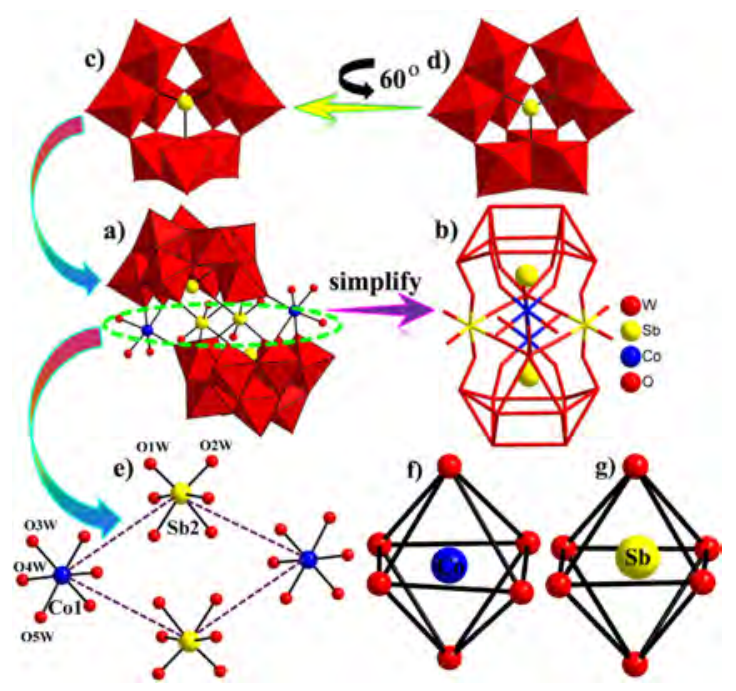

Fig. 1. (a) Combined polyhedral/ball-and-stick representation of the molecular structure of 1a. (b) A simplified view of the molecule structure of 1a. (c) The trivacant Keggin unit $\left[B-\beta-\mathrm{SbW}_{9} \mathrm{O}_{33}\right]^{9-}$ and (d) $\left[B-\alpha-\mathrm{SbW}_{9} \mathrm{O}_{33}\right]^{9-}$ precursor in 1a. (e) $\mathrm{A}\left\{\mathrm{Co}_{2} \mathrm{Sb}_{2}\right\}$ moiety in the center belt of two $\left[B-\alpha-\mathrm{SbW}_{9} \mathrm{O}_{33}\right]^{9-}$ units, with two different metal ions that constitute a rhombus. (f) The octahedral environment of $\mathrm{Co}^{2+}$ ion and (g $\mathrm{Sb}^{3+}$ ion. Color code: $\mathrm{Co}$ (blue), $\mathrm{Sb}$ (yellow), $\left\{\mathrm{WO}_{6}\right\}$ octahedra (red).

ing the formation of $\mathbf{1}$. This observation provides not only the synthetic viewpoint for this compound but also some new ideas for the rational design and synthesis of TMSPs, such as the addition of oxidants (such as $\mathrm{Ag}^{+}, \mathrm{S}_{2} \mathrm{O}_{8}{ }^{2-}$, and $\mathrm{MnO}_{4}^{-}$) for the preparation of novel TMSPs. In addition, discrete $\left\{\mathrm{Co}_{2} \mathrm{Sb}_{2}\left(\mathrm{H}_{2} \mathrm{O}\right)_{10}\left[B-\beta-\mathrm{SbW}_{9} \mathrm{O}_{33}\right]_{2}\right\}^{4-}$ polyoxoanions were regularly distributed in the -ABAB- mode along the $b$ and $c$ axes (Fig. S1). The phase purity of $\mathbf{1}$ was corroborated by the PXRD patterns (Fig. S2a). IR and TG analyses were performed to determine the structure and elemental composition, respectively (Figs. S2b and S3).

\subsection{Photocatalytic WO}

WO was performed to evaluate the photocatalytic ability of 1 in the system, utilizing $\left[\mathrm{Ru}(\mathrm{bpy})_{3}\right]^{2+}(1 \mathrm{mmol} / \mathrm{L})$ as the photosensitizer and $\mathrm{Na}_{2} \mathrm{~S}_{2} \mathrm{O}_{8}(5 \mathrm{mmol} / \mathrm{L})$ as the sacrificial electron acceptor in sodium borate buffer $(80 \mathrm{mmol} / \mathrm{L}, \mathrm{pH} 8.5,10 \mathrm{~mL})$ under visible-light irradiation $(\lambda=460 \mathrm{~nm})$ for $\mathrm{O}_{2}$ evolution.

The proposed catalytic mechanism of $\mathbf{1}$ for the light-driven WO is depicted in Fig. 2. Fig. 3 illustrates the amount of $\mathrm{O}_{2}$ evolution over 1 under different $\mathrm{pH}$ conditions. Evidently, $\mathrm{O}_{2}$ evolution was very quick, reaching a plateau in $120 \mathrm{~s}$ due to the consumption of the sacrificial electron acceptor, $\mathrm{Na}_{2} \mathrm{~S}_{2} \mathrm{O}_{8}$ [36,37].

A higher $\mathrm{pH}$ is thermodynamically favorable for WO; thus, the reaction at pH 8.0 with 1 showed poor activity. When the buffer $\mathrm{pH}$ was raised to 8.5 , the amount of $\mathrm{O}_{2}$ evolved reached $7.7 \mu \mathrm{mol}$ with a higher $\mathrm{O}_{2}$ yield of $30.8 \%$, TON of 193 , TOFinitial of $5.3 \mathrm{~s}^{-1}$, and $\Phi_{\mathrm{QY}}$ of $36.2 \%$ (see details in SI). However, upon continuously increasing the $\mathrm{pH}$ to 9.0, the amount of $\mathrm{O}_{2}$ evolved suddenly decreased from 7.7 to $5.9 \mu \mathrm{mol}$, and the corresponding $\mathrm{O}_{2}$ yield, TON, and $\Phi_{\mathrm{QY}}$ also decreased to $23.6 \%, 148$, and 


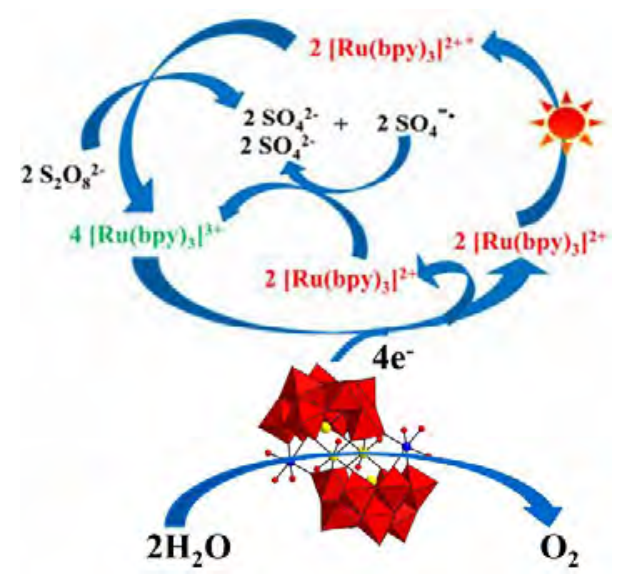

Fig. 2. Photocatalytic water oxidation catalyzed by 1 .

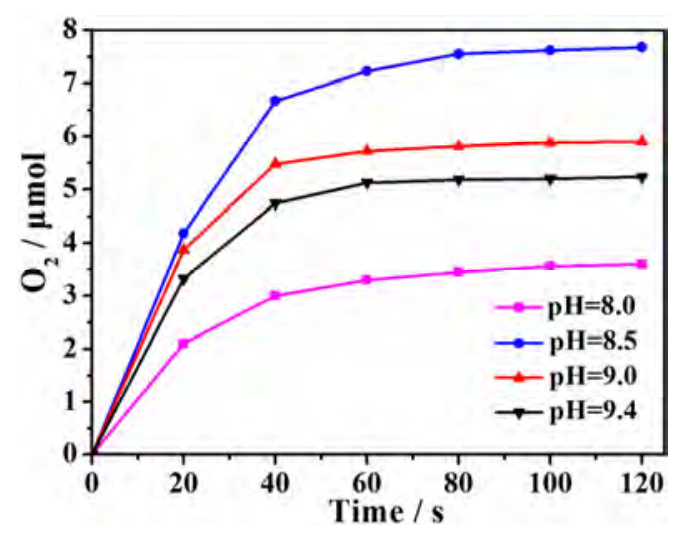

Fig. 3. Kinetics of $\mathrm{O}_{2}$ evolution in the photocatalytic system under various $\mathrm{pH}$ conditions. Conditions: LED lamp $(\lambda=460 \mathrm{~nm}), 5.0 \mathrm{mmol} / \mathrm{L}$ $\mathrm{Na}_{2} \mathrm{~S}_{2} \mathrm{O}_{8}, 1 \mathrm{mmol} / \mathrm{L}\left[\mathrm{Ru}(\mathrm{bpy})_{3}\right]^{2+}, 4 \mu \mathrm{mol} / \mathrm{L} \mathbf{1}, 80 \mathrm{mmol} / \mathrm{L}$ sodium borate buffer, total reaction volume is $10 \mathrm{~mL}$.

$34.2 \%$, respectively. The main reason for this phenomenon is the possible decomposition of the photosensitizer $\left[\mathrm{Ru}(\mathrm{bpy})_{3}\right]^{2+}$ at high $\mathrm{pH}$ during the photocatalytic process.

Moreover, other factors influencing the photocatalytic reaction, including the concentration of photosensitizer the and sacrificial electron acceptor, were systematically studied when the concentration of 1 was $4.0 \mu \mathrm{mol} / \mathrm{L}$ (Figs. S4 and S5). The $\mathrm{O}_{2}$ yield first showed a rapid increase as the concentration of [Ru(bpy) $\left.{ }_{3}\right] \mathrm{Cl}_{2}$ and $\mathrm{Na}_{2} \mathrm{~S}_{2} \mathrm{O}_{8}$ was increased up to $1.0 \mathrm{mmol} / \mathrm{L}$ and $5 \mathrm{mmol} / \mathrm{L}$, respectively, and then presented an unapparent increasing trend upon a further increase in the concentrations of $\left[\mathrm{Ru}(\mathrm{bpy})_{3}\right] \mathrm{Cl}_{2}$ and $\mathrm{Na}_{2} \mathrm{~S}_{2} \mathrm{O}_{8}$. Furthermore, it could be seen from Fig. 4 that $\mathrm{O}_{2}$ evolution was almost absent or negligibly small in the absence of light, $\mathrm{Na}_{2} \mathrm{~S}_{2} \mathrm{O}_{8}$, or catalyst $\mathbf{1}$. Thus, light, catalyst, photosensitizer, and sacrificial electron acceptor are essential factors for this WO system. As is known, the hydrolytic stability of POMs may be influenced by various factors, in which the POMs may decompose into catalytically active oxide nanoparticles. We compared the photocatalytic kinetic behavior between $\mathbf{1}$ and a benchmark homogeneous WOC, $\left[\mathrm{Co}_{4}\left(\mathrm{H}_{2} \mathrm{O}\right)_{2}\left(\mathrm{PW}_{9} \mathrm{O}_{34}\right)_{2}\right]^{10-}$, under the same reaction conditions. The amount of oxygen evolution from 1 was higher than that from $\left[\mathrm{Co}_{4}\left(\mathrm{H}_{2} \mathrm{O}\right)_{2}\left(\mathrm{PW}_{9} \mathrm{O}_{34}\right)_{2}\right]^{10-}$ (Fig. S6).

UV spectra of the aqueous solution and IR spectra were rec-

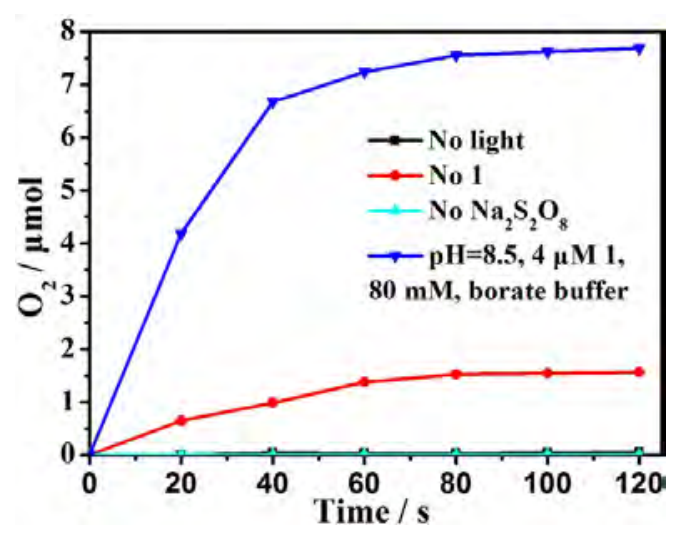

Fig. 4. Kinetics of $\mathrm{O}_{2}$ formation in the photocatalytic system without (a) light (black), (b) 1 (red), and (c) $\mathrm{Na}_{2} \mathrm{~S}_{2} \mathrm{O}_{8}$ (cyan).

orded to probe the catalyst stability. As shown in Figs. S7-S9, the UV spectra of $\mathbf{1}$ in the sodium borate buffer were monitored

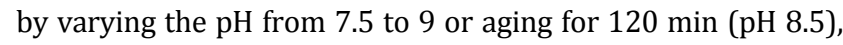
and no apparent changes were observed. There was no absorption band between 500 and $600 \mathrm{~nm}$ in the spectrum of 1 because of the rather weak absorbance corresponding to the Co-centered $d-d$ transitions, consistent with previous reports [38]. To further investigate the stability of $\mathbf{1}$ during photocatalytic WO, we carried out tetra- $n$-heptylammonium nitrate $\left(\mathrm{THp} \mathrm{ANO}_{3}\right)$-toluene extraction, which is proved to be an effective method for extracting POMs from the reaction solutions [39].

As shown in Table S4, after extracting 1 from the solutions before and after the reaction, there was almost no cobalt ion present in the solution. We also measured the $\mathrm{O}_{2}$ evolution dynamic curves at a low concentration of $\mathrm{Co}^{2+}(0.05 \mu \mathrm{mol} / \mathrm{L})$ under the optimal reaction conditions (Fig. S10). The blue and red curves represent the kinetics of $\mathrm{O}_{2}$ formation with 4 $\mu \mathrm{mol} / \mathrm{L} 1$ and $0.05 \mu \mathrm{mol} / \mathrm{L} \mathrm{Co}^{2+}$, respectively, in the photocatalytic system. Second, capillary electrophoresis was applied to detect the stability of $\mathbf{1}$ in the WO system. In this method, chemical species in the interior of a small capillary filled with an electrolyte are separated according to their charge to size ratio. Therefore, this method was carried out to investigate the stability of $\mathbf{1}$ during photocatalytic water oxidation. Although the characteristic peaks of $\mathbf{1}$ before and after the photocatalytic reactions shifted slightly to the right, they basically remained unchanged (Fig. 5). The reason for this shift was the change in the electrolyte concentration before and after the WO reaction. No extra peaks due to Co were observed in the electropherogram after the WO experiment. The results of capillary electrophoresis demonstrated that the structure of $\mathbf{1}$ was unchanged after the WO reactions. Moreover, the IR spectrum of the recovered catalyst $\mathbf{1}$ after the first run was consistent with that of the unused $\mathbf{1}$, which is a positive proof for the structural integrity of 1 (Fig. S11).

\section{Conclusions}

In summary, we synthesized a unique dicobalt-substituted sandwich-type tungstoantimonate $\mathbf{1}$ within a rare octahedral 


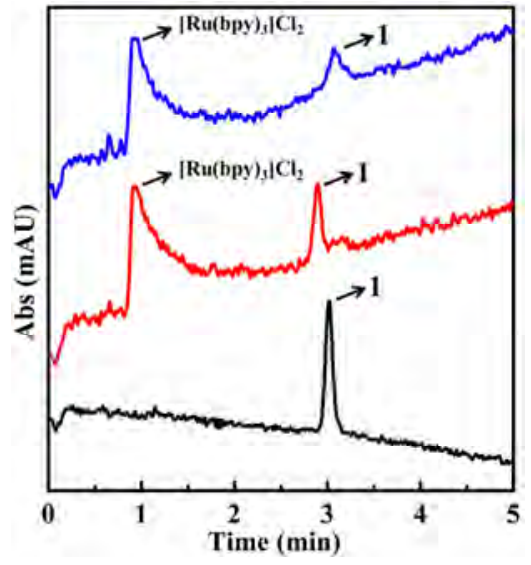

Fig. 5. Electropherogram of 1 . Black line: $4 \mu \mathrm{mol} / \mathrm{L}$ of 1 in $80 \mathrm{mmol} / \mathrm{L}$ sodium borate buffer solution ( $\mathrm{pH} 8.5$ ); red line: $4 \mu \mathrm{mol} / \mathrm{L}$ of $\mathbf{1}$ in 80 $\mathrm{mmol} / \mathrm{L}$ sodium borate buffer solution ( $\mathrm{pH}$ 8.5) containing $\left[\mathrm{Ru}(\mathrm{bpy})_{3}\right] \mathrm{Cl}_{2}(1.0 \mathrm{mmol} / \mathrm{L})$ and $\mathrm{Na}_{2} \mathrm{~S}_{2} \mathrm{O}_{8}(5.0 \mathrm{mmol} / \mathrm{L})$ before illumination; blue line: $4 \mu \mathrm{mol} / \mathrm{L}$ of $\mathbf{1}$ in $80 \mathrm{mmol} / \mathrm{L}$ sodium borate buffer solution (pH 8.5) containing $\left[\mathrm{Ru}(\mathrm{bpy})_{3}\right] \mathrm{Cl}_{2}(1.0 \mathrm{mmol} / \mathrm{L})$ and $\mathrm{Na}_{2} \mathrm{~S}_{2} \mathrm{O}_{8}(5.0$ $\mathrm{mmol} / \mathrm{L}$ ) after 2 min of illumination.

$\left\{\mathrm{SbO}_{3}\left(\mathrm{H}_{2} \mathrm{O}\right)_{3}\right\}$ bridge and systematically characterized the compound by multiple techniques. We found that $\mathbf{1}$ acts as an efficient and stable photocatalytic WO catalyst. Under the optimal photocatalytic conditions (photoirradiation at $\lambda=460$ $\mathrm{nm},\left[\mathrm{Ru}(\mathrm{bpy})_{3}\right] \mathrm{Cl}_{2}$ as the photosensitizer, $\mathrm{Na}_{2} \mathrm{~S}_{2} \mathrm{O}_{8}$ as the oxidant in a basic borate buffer), the TON and $\mathrm{O}_{2}$ yield were as high as 193 and $30.8 \%$, respectively. $\Phi_{\mathrm{QY}}$ and $\mathrm{TOF}_{\text {initial }}$ in the first $20 \mathrm{~s}$ of the reaction were $36.2 \%$ and $5.3 \mathrm{~s}^{-1}$, respectively. This study presents the feasibility of the design and use of Co-containing inorganic clusters as effective WOCs, and the discovery of this novel Co-based catalyst enriches the photocatalytic WO catalyzed by polyoxometalates.

\section{Acknowledgments}

This research was financially supported by the National
Natural Science Foundation of China (Grants No. 21773096), the Fundamental Research Funds for the Central Universities (lzujbky-2018-k08), and the Natural Science Foundation of Gansu Province (17JR5RA186).

\section{References}

[1] L. L. Duan, F. Bozoglian, S. Mandal, B. Stewart, T. Privalov, A. Llobet, L. C. Sun, Nat. Chem., 2012, 4, 418-423.

[2] J. Q. Lin, Q. Han, Y. Ding, Chem. Rec., 2018, 18, 1531-1547.

[3] M. D. Symes, L. Cronin, Nat. Chem., 2013, 5, 403-409.

[4] X. B. Chen, C. Li, M. Grätzel, R. Kostecki, S. S. Mao, Chem. Soc. Rev., 2012, 41, 7909-7937.

[5] B. M. Hunter, H. B. Gray, A. M. Müller, Chem. Rev., 2016, 116, 14120-14136.

[6] J. Lin, B. Ma, M. Chen, Y. Ding, Chin. J. Catal., 2018, 39, 463-471.

[7] J. W. Huang, Y. Zhang, Y. Ding, ACS Catal., 2017, 7, 1841-1845.

[8] B. Limburg, E. Bouwman, S. Bonnet, Coord. Chem. Rev., 2012, 256, 1451-1467.

[9] Q. Lan, Z. M. Zhang, C. Qin, X. L. Wang, Y. G. Li, H. Q. Tan, E. B. Wang, Chem.-Eur. J., 2016, 22, 15513-15520.

[10] J. Guan, C. Ding, R. Chen, B. Huang, X. Zhang, F. Fan, F. Zhang, C. Li, Chem. Sci., 2017, 8, 6111-6116.

[11] S. Chen, S. Shen, G. Liu, Y. Qi, F. Zhang, C. Li, Angew. Chem. Int. Ed, 2015, 54, 3047-3051.

[12] T. Zhang, C. Wang, S. B. Liu, J. L. Wang, W. B. Lin, J. Am. Chem. Soc., 2014, 136, 273-281.

[13] J. C. Liu, Q. Han, L. J. Chen, J. W. Zhao, C. Streb, Y. F. Song, Angew. Chem. Int. Ed., 2018, 57, 8416-8420.

[14] S. S. Wang, G. Y. Yang, Chem. Rev., 2015, 115, 4893-4962.

[15] H. J. Lv, Y. V. Geletii, C. C. Zhao, J. W. Vickers, G. B. Zhu, Z. Luo, J. Song, T. Q. Lian, D. G. Musaev, C. L. Hill, Chem. Soc. Rev., 2012, 41, 7572-7589.

[16] Q. Yin, J. M. Tan, C. Besson, Y. V. Geletii, D. G. Musaev, A. E. Kuznetsov, Z. Luo, K. I. Hardcastle, C. L. Hill, Science, 2010, 328, 342-345.

[17] L. Yu, Y. Ding, M. Zheng, Appl. Catal. B, 2017, 209, 45-52.

[18] L. Yu, J. Q. Lin, M. Zheng, M. D. Chen, Y. Ding, Chem. Commun., 2018, 54, 354-357.

[19] Q. Han, Y. Ding, Dalton Trans., 2018, 47, 8180-8188.

\section{Graphical Abstract}

\section{Chin. J. Catal., 2019, 40: 953-958 doi: S1872-2067(19)63358-9}

\section{A novel dicobalt-substituted tungstoantimonate polyoxomet- alate: Synthesis, characterization, and photocatalytic water oxidation properties}

Qing Han, Di Sun, Junwei Zhao, Xiangming Liang, Yong Ding * Lanzhou University; Lanzhou Institute of Chemical Physics, Chinese Academy of Sciences; Shandong University; Henan University

The one-pot assembly reaction of a trilacunary $\left[B-\alpha-\mathrm{SbW}_{9} \mathrm{O}_{33}\right]^{9-}$ precursor with $\mathrm{Co}^{2+}$ and $\mathrm{Ag}^{+}$in an aqueous medium led to the isolation of a novel tungstoantimonate $\left\{\mathrm{Co}_{2} \mathrm{Sb}_{2}\left(\mathrm{H}_{2} \mathrm{O}\right)_{10}\left[B-\beta-\mathrm{SbW}_{9} \mathrm{O}_{33}\right]\right.$ ${ }_{2\}^{4-}}$ (1a), which showed efficient catalytic activity for water oxidation with a remarkable TON of 193 , TOF initial of $5.3 \mathrm{~s}^{-1}, \mathrm{O}_{2}$ yield of $30.8 \%$, and quantum yield $\left(\Phi_{\mathrm{QY}}\right)$ of $36.2 \%$.

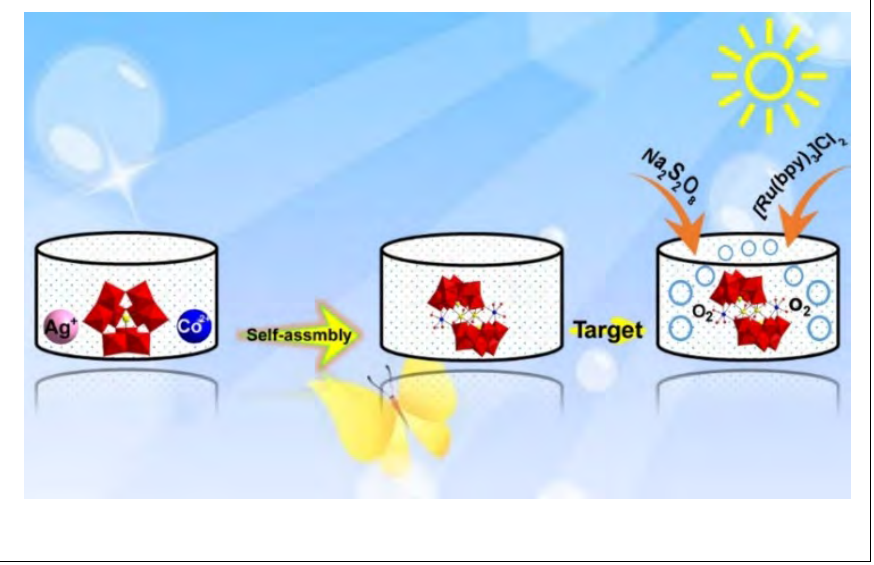


[20] X. B. Han, Y. G. Li, Z. M. Zhang, H. Q. Tan, Y. Lu, E. B. Wang, J. Am. Chem. Soc., 2015, 137, 5486-5493.

[21] Y. V. Geletii, Z. Q. Huang, Y. Hou, D. G. Musaev, T. Q. Lian, C. L. Hill, J. Am. Chem. Soc., 2009, 131, 7522-7523.

[22] Z. Huang, Z. Luo, Y. V. Geletii, J. W. Vickers, Q. Yin, D. Wu, Y. Hou, Y. Ding, J. Song, D. G. Musaev, C. L. Hill, T. Lian, J. Am. Chem. Soc., 2011, 133, 2068-2071.

[23] X. B. Han, Z. M. Zhang, T. Zhang, Y. G. Li, W. Lin, W. You, Z. M. Su, E. B. Wang, J. Am. Chem. Soc., 2014, 136, 5359-5366.

[24] F. Y. Song, Y. Ding, B. C. Ma, C. M. Wang, Q. Wang, X. Q. Du, S. Fu, J. Song, Energy Environ. Sci., 2013, 6, 1170-1184.

[25] R. Xiang, Y. Ding, J. Zhao, Chem. Asian J., 2014, 9, 3228-3237.

[26] J. Wei, Y. Y. Feng, P. P. Zhou, Y. Liu, J. Y. Xu, R. Xiang, Y. Ding, C. C. Zhao, L. Y. Fan, C. W. Hu, ChemSusChem, 2015, 8, 2630-2634.

[27] L. H. Bi, M. Reicke, U. Kortz, B. Keita, L. Nadjo, R. J. Clark, Inorg. Chem., 2004, 43, 3915-3920.

[28] T. Yamase, K. Fukaya, H. Nojiri, Y. Ohshima, Inorg. Chem., 2006, 45, 7698-7704.

[29] C. C. Zhao, C. S. Kambara, Y. Yang, A. L. Kaledin, D. G. Musaev, T. Q. Lian, C. L. Hill, Inorg. Chem., 2013, 52, 671-678.
[30] A. Dolbecq, J. D. Compain, P. Mialane, J. Marrot, E. Rivière, F. Sécheresse, Inorg. Chem., 2008, 47, 3371-3378.

[31] T. McGlone, L. Vilà-Nadal, H. N. Miras, D. L. Long, J. M. Poblet, L. Cronin, Dalton Trans., 2010, 39, 11599-11604.

[32] M. Carraro, B. S. Bassil, A. Sorarù, S. Berardi, A. Suchopar, U. Kortz, M. Bonchio, Chem. Commun., 2013, 49, 7914-7916.

[33] I. V. Kalinina, N. V. Izarova, U. Kortz, Inorg. Chem., 2012, 51, 7442-7444.

[34] J. Liu, J. Luo, Q. Han, J. Cao, L. Chen, Y. Song, J. Zhao, J. Mater. Chem. C, 2017, 5, 2043-2055.

[35] M. Bösing, I. Loose, H. Pohlmann, B. Krebs, Chem. - Eur. J., 1997, 3, 1232-1237.

[36] X. Du, Y. Ding, F. Song, B. Ma, J. Zhao, J. Song, Chem. Commun., 2015, 51, 13925-13928.

[37] P. E. Car, M. Guttentag, K. K. Baldridge, R. Alberto, G. R. Patzke, Green Chem., 2012, 14, 1680-1688.

[38] W. C. Chen, X. L. Wang, C. Qin, K. Z. Shao, Z. M. Su, E. B. Wang, Chem. Commun., 2016, 52, 9514-9517.

[39] J. W. Vickers, H. Lv, M. J. Sumliner, G. Zhu, Z. Luo, D. G. Musaev, Y. V. Geletii, C. L. Hill, J. Am. Chem. Soc., 2013, 135, 14110-14118.

\section{一例新型二钴取代锑铇酸盐：合成、表征及光催化水氧化性能}

韩 庆 ${ }^{\mathrm{a}}$, 孙 頔 ${ }^{\mathrm{c}}$, 赵俊伟 ${ }^{\mathrm{d}}$, 梁向明 ${ }^{\mathrm{a}}$, 丁 勇, ${ }^{\mathrm{a}, \text {, }}$

$\mathrm{a}$ 兰州大学化学化工学院, 甘肃省有色金属重点实验室, 功能有机分子国家重点实验室, 甘肃兰州730000

b 中国科学院兰州化学物理研究所羰基合成与选择氧化国家重点实验室，甘肃兰州730000

c山东大学化学化工学院, 胶体与界面化学教育部重点实验室, 山东济南250100

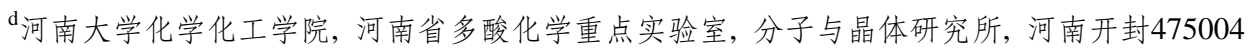

摘要: 太阳能分解水制氢作为解决当前能源危机和环境危机最理想和最有前途的策略之一正受到越来越多的关注. 在人 工模拟光合作用过程中, 水的氧化 $\left(2 \mathrm{H}_{2} \mathrm{O} \rightarrow 4 \mathrm{H}^{+}+\mathrm{O}_{2}+4 \mathrm{e}^{-}\right)$是整个反应过程的瓶颈, 因此开发高效稳定水氧化催化剂是提 高人工光合作用性能的关键. 在过去的几十年里, 全世界科研工作者已经为设计合成高效稳定的均相和多相水氧化催化 剂做了大量工作. 在均相水氧化领域, 多金属氧酸盐(简称多酸)作为一类结构多样的多金属氧簇化合物, 由于其良好的氧 化、热、水解稳定性, 能够在不改变结构的前提下进行快速、可逆、多电子转移反应, 因而受到广泛关注. 2009年, Hill课 题组首次将四钓多酸用于光驱动水氧化体系. 随后, 他们报道了不含贵金属的四钴多酸 $\left(\mathrm{Co}_{4}\left(\mathrm{H}_{2} \mathrm{O}\right)_{2}\left(\mathrm{PW}_{9} \mathrm{O}_{34}\right)_{2}\right]^{10-}$ 催化水氧 化的工作. 王恩波团队和我们课题组在该领域也进行了一些深入研究.

值得注意的是, 由于 $\mathrm{Sb}^{3+}$ 易于在水溶液中水解, 这在很大程度上阻碍了锑铇酸盐前驱体与过渡金属离子结合形成多酸 簇, 所以导致有关过渡金属取代铇铮酸盐的报道非常少. 本文采用一锅自组装策略, 利用缺位多酸前驱体 $\left[B-\alpha-\mathrm{SbW}_{9} \mathrm{O}_{33}\right]^{9-}$ 与 $\mathrm{Co}^{2+}$ 在弱酸性条件下反应, 首次合成出一个结构新颖的夹心型锑铇酸盐 $\mathrm{Na}_{4}\left[\mathrm{Co}_{2}\left(\mathrm{H}_{2} \mathrm{O}\right)_{6} \mathrm{Sb}_{2}\left(\mathrm{H}_{2} \mathrm{O}\right)_{4}\left(B-\beta-\mathrm{SbW}_{9} \mathrm{O}_{33}\right)_{2}\right] \cdot 39 \mathrm{H}_{2} \mathrm{O}$ (1). 在可见光照射下, 可有效催化水氧化反应, 在最佳反应条件 $\left(\mathrm{Na}_{2} \mathrm{~S}_{2} \mathrm{O}_{8}\right.$ 为牺牲电子受体, $\left[\mathrm{Ru}(\mathrm{bpy})_{3}\right] \mathrm{Cl}_{2}$ 为光敏剂, 缓冲溶液 $\mathrm{pH}=8.5)$ 下, 反应的转化数和氧气收率最高分别可达 193 和 $30.8 \%$, 初始量子效率和初始转化频率分别为 $36.2 \%$ 和 $5.3 \mathrm{~s}^{-1}$. 紫 外-可见吸收光谱、反应前后催化剂的红外光谱、毛细管电泳及甲苯萃取等实验结果表明, 该锑铇酸盐 $\mathbf{1}$ 是一个稳定的光催 化水氧化催化剂.

关键词: 光驱动水氧化; 锑钨酸盐; 自组装

收稿日期: 2019-01-23. 接受日期: 2019-03-25. 出版日期: 2019-06-05.

*通讯联系人. 电子信箱: dingyong1@lzu.edu.cn

基金来源：国家自然科学基金(21773096); 中央高校基本科研业务费专项资金(lzujbky-2018-k08); 甘肃省自然科学基金 (17JR5RA186).

本文的电子版全文由Elsevier出版社在ScienceDirect上出版(http://www.sciencedirect.com/science/journal/18722067). 